\title{
How to Tell the Red Story in a New Era
}

\begin{abstract}
Jun $\mathrm{Xu}$
School of Marxism, China Jiliang University, Hangzhou 310018, China

*Corresponding author. Email: $1522457122 @ q q . c o m$

ABSTRACT

Red stories are not only a piece of red memory, but also carry the red tradition formed by the flesh and blood of the past, and are historical scrolls carved by the blood and lives of the old revolutionary soldiers. Good red storytelling can effectively promote the spread of red culture, which not only provides unlimited spiritual pillars for revolutionary soldiers in the new era, but also becomes a powerful "booster" for the country to improve the combat effectiveness of the army. This paper discusses the importance of good red storytelling in the new era and the countermeasures for better red education, better transmission of the red gene to the next generation, and the promotion of the revolutionary spirit, so that the red gene can be passed forever and the theme of the times can be played.
\end{abstract}

Keywords: Red story, New era, Red culture education, Inheriting red genes.

\section{INTRODUCTION}

In this magnificent 100-year history of the Communist Party of China (CPC), the CPC has united and led the Chinese people, overcoming mountain after mountain, hurdle after hurdle, and achieving victory after victory, leaving an indelible legacy of great merit in the history of the Chinese nation. During the great years, countless revolutionary ancestors brought forth many admirable red stories with their blood and sweat, leaving behind a heroic epic full of tears and blood. Know the way forward and start a new journey. In the new era, telling red stories, passing on red culture and drawing on red power will be a powerful impetus to the further development of the cause of socialism with Chinese characteristics and the great project of building the Party.

\section{RED STORY CONCEPT DEFINITION}

Red is the colour of the Chinese people, symbolising hope, harmony and beauty. Stories are the best and most vivid vehicles for culture. Red stories are about what happened when the Chinese Communist Party united and led the Chinese people to victory in the New Democratic Revolution, especially the stories of some of the great men and heroes of the revolution who were the founders of the new China, carrying the ideals and beliefs of the Communists. As an important part of the story of Chinese history, the Red Story isalso a solid ground and a vivid carrier of socialist thought with Chinese characteristics in the new era. Only on the basis of an in-depth understanding of the history of New China, the history of the Communist Party of China, the history of reform and opening up and the development of socialism can we have a profound understanding. The selection and distillation of classic red stories, the telling of the suffering and glory of the Communist Party of China over the past hundred years, the vigorous discovery of red stories and the telling of good red stories are the new propositions and tasks given to us by the times.

\section{THE NECESSITY OF TELLING GOOD RED STORIES IN THE NEW ERA}

\subsection{Red Stories are the Best Textbooks}

Red stories are the best and most vivid textbooks for spreading red education. Encouraging Party members and cadres to take action and lead the masses into the new era requires telling the red story, carrying on the fine revolutionary tradition, revisiting the red memory and awakening the red gene in us. The centuries-old history of the Communist Party of China is part of the Red Story, a true portrayal of our Party's practical exploration and progress over these centuries. It is like a red educational base, a "spiritual torch" scattered over 9.6 million square kilometers of land. They are not only an immortal saga of the Communist Party's "work for the happiness of the people", but also a powerful spiritual impetus for Party members, cadres and the masses in the new era to struggle steadfastly for the great rejuvenation of the Chinese nation. In this new era, 
we need to give full play to the textbook role of the red story, to tell it well and to receive red education. We will continue to strengthen the joy of the Communist Party members to "worry about the world first, then worry about the world", which is deeply rooted in our hearts, and enhance our self-confidence to achieve the prosperity of our country. Prosperity and prosperity.

\subsection{Red Stories are the Best Nourishment}

Telling the red story in the new era can play its role as a nourishing agent, and if we want to remain true to our roots in the face of such intricacies, we must remember where and how the red regime came from. No matter how far we go, we must never forget the way we came. By looking back at the road we have travelled, we can become more acutely aware of how difficult it was to achieve the Red Regime, how hard it was for New China to come about and how hard it was for socialism with Chinese characteristics to come about. In this new era of telling the red story, playing its role as a nourishing agent and receiving "red education", we should always remember the great sacrifices made by the revolutionary martyrs for the national independence and liberation of the people in the earthquake zone, and the immortal achievements left by the revolutionary martyrs for the construction of new China, and strive to learn from the deeds of the revolutionary martyrs and the examples of the times, and Moving on. Red stories not only record a rich history and vivid deeds, but also leave behind a wealth of incomparable spiritual wealth [4]. These red spirits have the power of the times to transcend time and space, to stir the hearts and minds of people, and to inspire and strengthen. Red stories are the best nourishment, and it is important to inherit and carry forward the fine traditions that have coalesced in the practice of struggle and construction, to realia the resonance of red resources and the spirit of the times, and to make unremitting efforts to realia the goal of a modern socialist power.

\subsection{Red Stories are the Best Inspiring Pieces}

In the nearly 100-year history of the Chinese revolutionary struggle, the Communist Party of China has never forgotten its original intention and mission, and has led the Chinese people in their tireless struggle for national prosperity and people's happiness, writing great works and moving chapters. At the starting point of the new era, we are telling the red story, receiving red education and using red memorials and red museums as "inspirational classrooms" to practise revolutionary traditions, patriotism and ideals and beliefs. Education, making full use of the charm of the red story, inspires party members and cadres and the people to take up their role in the new era. Standing at the starting point of the new era of red inspiration education, we must firmly uphold the concept of "people-oriented" development, adhere to the goal of a better life for the people, sincerely serve the people, recitalist the Chinese nation and seek happiness for the Chinese people. This requires that the people's support or disapproval, approval or disapproval, delight or displeasure, and agreement or disapproval be used as the passing line for evaluating whether our work is on target, and that we strive to address the most direct and realistic interests of the people, so that all Chinese people can live together in harmony. In the historical process of the great national renaissance, the Chinese people can enjoy happiness and glory together.

The "red bases" are the essence of the Chinese revolution, and the "red stories" are a recreation of the Chinese revolution. When Party members and cadres receive "red education", they must truly absorb the nourishment of the Party, "nourish the soul, create the soul", replenish the "calcium" of ideals and beliefs, remember the original desire We must also remember our mission and always stand up for the people.

\section{SOME STRATEGIES TO TELL GOOD RED STORIES IN THE NEW ERA}

\subsection{Transfering Knowledge}

Red resources are the carriers of the red gene. Every red site or place is a valuable red resource. In this new era, we must make full use of these resources to build, manage and use these red relics and revolutionary sites so that they can become classrooms and teaching materials for telling the red story.

When General Secretary Xi Jigging conducted visits and research in various places, he would first visit local revolutionary memorials and meticulously observe the exhibits on display, and repeatedly pointed out that the revolutionary memorials and exhibits on display carry the most important red gene and incomparable spiritual value. We should make full use of exhibitions to tell the red story, using historical photos, paintings, sculptures and multimedia interactive scenes to tell the red story, so that the red spirit is neutralism in the exhibits, moved in the exhibitions and brought to life in the participatory experience [4].

General Secretary Xi Jigging has always been very concerned about issues related to revolutionary cultural relics. He stressed, "Let cultural relics speak, tell people the wisdom of history, and inspire our national pride and self-confidence." Most revolutionary cultural relics have weeping stories and present the revolutionary spirit that has shone through the ages. In this new era, we must make good use of revolutionary relics to impart knowledge and inspire patriotism among the people. 


\subsection{Stimulating Emotions}

In order to be able to educate people through red storytelling, it is necessary to use a method that touches the emotions, i.e. stimulates them. Storytelling must borrow things to express emotions and move people. "Nothing touches the heart like emotion." How to tell a dusty story of bloody history in a vivid, interesting, intriguing and educational way requires that the narrator, when telling the story, has to incorporate emotions into the history and plot of the story in order to tell it sincerely, so that different audiences can feel the moving and inspiring spiritual power through these stories. It begins with a deep appreciation of the spiritual content of the story, a deep understanding of what is happening behind the scenes, and a grasp of the moving intentions, ideas and details of the story.

Technology is constantly developing and the times are advancing. In order to tell the red story better in the new era, we have to adopt expressions that are more acceptable to people, so that they can better understand and remember, and stimulate people's emotions to achieve the effect of diving into the night with the wind. Things are silent. Telling the red story should be combined with the characteristics of the times, constantly innovate, actively promote the integration of red culture into ecological culture, historical culture and folk culture, effectively integrate the red gene into the whole process of communication, learn from the world to learn popular elements, integrate into the times and make more contributions. At the same time, it is important to constantly innovate the concept of work and adopt new forms, methods and approaches such as Jitterbug, Weirdo, We Chat and live streaming in order to improve the dissemination, guidance and influence as well as and the infectious power of red stories. Good red literature is sure to bring rich nourishment of emotions, good moral education and correct guidance of values, set the spiritual high ground and work together to catch up and surpass, and contribute to the overall building of a modern socialist country.

\subsection{Strong Will}

General Secretary Xi Jigging once affectionately said during a survey in Hangzhou: "I am here today, and I have been educated. As a member of the Communist Party and a responsible cadre of the Communist Party, I must continue to be educated, baptized and constantly educated. Be inspired and perform my duties well." The hard work and solemn commitment of the Communist Party of China has provided endless energy to advance the cause of the Party and the people and to realia the Chinese dream of the great rejuvenation of the Chinese nation. Telling a good red story can fill the "calcium" and "soul" of party members and cadres in the new era. In today's socialist market economy, some party members and cadres have lost their ideals and beliefs and have a weak sense of purpose. How party members and cadres can maintain their advanced purity and strong will and not be eroded by wrong ideas and backward consciousness is deeply related to the survival of the party. Through red education and red storytelling, it is conducive to guiding the majority of party members and cadres to firm up their original mission, trace the red memory, vigorously transmit the red gene, and carry forward the glorious tradition and fine style of the party; it can help the majority of party members and cadres to feel sublime from the revolutionary tradition and draw strength from the red gene, so as to consciously sublimate the spiritual realm, stimulate the pursuit of values, and perpetuate the party's advancement and purity.

A nation that forgets its heroes has no soul, and a nation that does not understand history has no roots. Telling the red story well requires us to establish a strong will, which is the most valuable spiritual asset for the continuation of the glory and the future. A strong will and adherence to the right values will not lead to a loss of direction.

\subsection{Strong Conviction}

In this new era we must create a good educational atmosphere in society, schools and families and be the people who water and cultivate the soil for children so that they can understand why the national flag, the party flag and the red scarf are flown on their chests and why these have been so red since childhood and tell them more about the country and the stories of its development, the stories of revolutionary ancestors, heroes and The stories of scientists helped them to develop a correct outlook on life and values, to fasten the first buttons of life, to enable them to sow the seeds of patriotism and love for the Party, and to enable their young hearts to develop a patriotic heart and strong beliefs.

"The ideal belief is the communist spiritual 'calcium', no ideal belief, ideal belief is not firm, the spirit will be 'lack of calcium', will get 'cartilage disease '." These words of Xi Jigging vividly reveal that the main reason why the Chinese Communist Party has united and led its people to one major victory after another is that the Communists have unnervingly made the communist ideal their lifelong pursuit and mission. Telling the "red story" is to show the revolutionary spirit through these real historical events, so that contemporary university students can feel the powerful power of ideals and beliefs inspired by the revolutionary spirit, and firmly internal the value of socialism with Chinese characteristics as an internal motivation on the road to self-fulfilment. In the new situation, in the face of the impact of pluralistic values in the context of globalization, the challenge of the ideology of Western 
hostile forces, and the negative influence of many erroneous ideas in cyberspace, we are deeply affected and inspired by the vivid "red stories" of the new generation of university students, which help them understand the current situation correctly and guide them to take resolute They saw death as a truth and an ideal, "It does not matter if you behead your head, only that the principle is right, kill Mia Gingham and future generations." It is because of this determination of the Chinese Communists to never change their original beliefs that has supported the Party and the people in achieving one great victory after another. As the future of the country and the hope of the nation, young people should inherit the legacy of their revolutionary ancestors, strengthen their faith in the Party, consciously set high ideals, be steadfast and strive to become excellent builders and successors of communism.

\subsection{Promoting Action}

Absorbing the power of the Red Story China's patriotic and dedicated spirit, university students are urged and guided to act and strive to become heroic role models in the new era. "A nation with hope cannot be without heroes, and a country with a future cannot be without pioneers." This is precisely because of the perseverance of revolutionary heroes, their will to work hard, their dedication, their selfless dedication and their patriotism to the public good. The spirit of selfless devotion and patriotism for the common good and the world at large still shine brightly despite the passage of time. Along with the continuous development of social and economic development, some phenomena of personal moral corruption have emerged in society. With the media's exaggerated propaganda, it has had a greater impact on the minds of university students whose values have not yet matured, as well as on the minds of our students. At present, they are all "post-95" and "post-00". Most of them are only children, and their special upbringing has made some university students accustomed to self-centred and lacking a certain spirit of devotion. This requires universities to make effective use of red resources in the process of ideological and political education, with the help of the selfless spirit of revolutionary heroes and the spirit of noble patriotism. General Secretary Xi Jigging once pointed out, "Striving together with the people and advancing together with the motherland, serving the people and devoting oneself to the motherland are the correct directions for the youth of contemporary China." He has always encouraged university students to take positive action by actively enrolling in various voluntary activities, going to the grassroots, rooting in the motherland, and contributing their wisdom and strength to the reduction and elimination of poverty. Telling the "red story" of the new era means using yesterday's role models to nurture today's heroes, so that university students can draw on the spiritual strength of their revolutionary forefathers who were dedicated to the country and the people, and inspire them to be more consciously and courageously today's role models in the new era.

\section{CONCLUSIONS}

History is about learning from the past. In the new era, we must tell the story of red culture, spread the theme of red culture, inherit the red gene, carry out red culture education, fully grasp the advantages of red resources through practical action, carry forward and continue to inherit the red tradition. We must better fulfil the cultural mission wntrusted to us by history, promote the overpopulation and dissemination of Marxism, comprehensively build a great modern socialist country in all respects and achieve the great rejuvenation of the Chinese nation.

\section{REFERENCES}

[1] Wang Congruity. Research on red cultural identity and patriotism among Yunnan university students [D]. Yunnan: Kunming University of Technology, 2015.

[2] Wang An, Chaos Ataxia. The five-fold logic that should be followed in telling the "red story" $[\mathrm{J}]$. Marxism and Reality, 2019, 6:179-185.

[3] Wang Lu. Passing on the red gene from generation to generation [EB/OL].

WWW.inhumane.com,2019-08-25.

[4] Bhang Xiaoping and Thu Jamaica. Hangzhou village revisits "the story of half a quilt", Xi Jigging stresses: telling the red story so that the red gene will be passed on from generation to generation

[EB/OL]. WWW.inhumane.com,2020-09-17.

[5] Central Literature Research Office, ed. Excerpts from Xi Spinning's Discourses on the Overall Strict Governance of the Party [M]. Central Literature Publishing House: Beijing, 2016:57. 